УДК 658.562+339.03:658.5

DOI: $10.15587 / 2313-8416.2015 .37940$

\title{
СИСТЕМНИЙ ПІДХІД В ОРГАНІЗАЦЇ̈ ОБЛАШТУВАННЯ ВНУТРІШНІХ ПРИМІЩЕНЬ В ПРОМИСЛОВОМУ ТА ЦИВІЛЬНОМУ БУДІВНИЦТВІ
}

\author{
(C) В. Б. Коваль
}

Розроблено алгоритм системного підходу в організації облаштування внутрішніх приміщень в промисловому та цивільному будівництві. Визначено оптимальну область існування системи по вихідним критеріям: V2 $\rightarrow$ min $i$ V2 $\rightarrow$ max, яка обмежена значеннями варійованих факторів по X1 від 392 до 500 грн., по X2 від 3 до 5 чоловік, по Х3 від 5 до 7 днів. Показано область існування системи, щзо забезпечує мінімальну вартість виконання робіт (менше 35000 грн.) за термін у 6 днів

Ключові слова: алгоритм, будівництво, внутрішні приміщення, механізм дї̈, облаштування, система, системний підхід

The algorithm of systematic approach in indoor arrangement in industrial and civil construction is developed. It is determined the optimum region for the system existence by exit criteria: $V 2 \rightarrow \min$ and $V 2 \rightarrow$ max, which is limited to values of varied factors X1 from 392 to $500 \mathrm{UAH}, \mathrm{X} 2$ from 3 to 5 people on X3 from 5 to 7 days. It is shown the existence of region that provides the minimum cost of work (less than 35,000 UAH) for a period of 6 days

Keywords: algorithm, construction, indoor, action mechanism, arrangement, system, system approach

\section{1. Вступ}

Системний підхід в останні роки широко застосовується в різних областях науки і виробництва [1, 2]. Робляться спроби використання системної методології у вирішенні завдань технології [3] та організації [4-6] промислового та цивільного будівництва. Відомо, що системний аналіз є одним 3 методів, що дозволяє розглядати будь-яку технологію будівельного виробництва як певний об'єкт 3 великим діапазоном зовнішніх i внутрішніх причинно-наслідкових зв'язків.

При використанні системного підходу особливо важливо правильно вибрати систему і методи вирішення завдань 3 підвищення іiі ефективності. Зазвичай, система утворюється двома складовими:

- зовнішнім оточенням, що включає в себе вхід і вихід системи, зв'язок із зовнішнім середовищем i зворотний зв'язок;

- внутрішньою структурою, тобто сукупністю взаємопов'язаних компонентів, що забезпечують процес впливу суб'єкта управління на об'єкт, переробку входу системи в ії вихід і досягнення цілей системи.

Внутрішні приміщення житлових та промислових споруд як систему можна представити єдніс-тю матеріальних і нематеріальних компонентів аналізованого об'єкта, його зовнішніх і внутрішніх зв'язків, що забезпечують раціональність інформа-ційних, виробничих, управлінських та інших процесів. \section{проблеми \\ 2. Літературний огляд i постановка \\ На сьогодні відомо три метода виконання} будівельних робіт: послідовний, паралельний i паралельно-послідовний [7]. При послідовному методі збільшується тривалість будівельних робіт. Однак послідовне облаштування приміщення проводиться без зупинки основного виробництва та характеризується зменшенням інтенсивності виконання будівельних за рахунок створення матеріальних запасів із тимчасовим їх використанням на вільних або резервних площах. При паралельному методі - виробництво будівельних робіт поєднане у часі та просторі з основним виробництвом. У зв'язку 3 тим, що всі внутрішні приміщення облаштовуються одночасно, тривалість будівельних робіт мінімальна і дорівнює тривалості всього обсягу виконання будівельно-монтажних робіт. Більш перспективним методом облаштування є паралельно-послідовний, який характеризується трохи більшою тривалістю проведення робіт в порівнянні 3 паралельним. В цьому методі передбачено проведення оздоблювальних робіт без зупинки всього будівельного виробництва за рахунок створення запасів напівфабрикатів і послідовного введення гілок паралельних технологічних ліній.

Тому актуальним $\epsilon$ спроба застосування системного підходу [8] до вирішення проблеми забезпечення зниження загальної вартості будівельних робіт і підвищення якості їх виконання при паралельному методі виконання робіт.

Об'єктом дослідження в даній роботі є облаштування внутрішніх перегородок приміщення житлової та промислової будівлі.

Метою роботи $є$ розробка алгоритму системного підходу та дії механізму системи в напрямку удосконалення традиційних схем облаштування внутрішніх приміщень промислових споруд за рахунок використання інноваційних будівельних матеріалів та математичного моделювання самого процесу по критеріям мінімальної загальної вартості та максимальної якості виконання робіт.

Для досягнення поставленої мети необхідно розв’язати такі задачі:

- розробити алгоритм системного підходу в облаштуванні внутрішніх приміщень житлових та 
промислових будівель, яка стане основою бази знань механізму дії системи;

- реалізувати механізм дії системи в напрямку мінімізації вартості виконання оздоблювальних робіт і високими показниками якості.

\section{3. Розробка алгоритму системного підходу в облаштуванні внутрішніх приміщень в промисловому та цивільному будівництві}

Відповідно, в якості об'єкта системи обрано умовне внутрішнє приміщення яке підлягає облаштуванню - зведення перегородок. Така система є відкритою, бо характеризується взаємодією об'єкта 3 зовнішнім середовищем і може бути представлена у вигляді такої схеми (рис. 1).

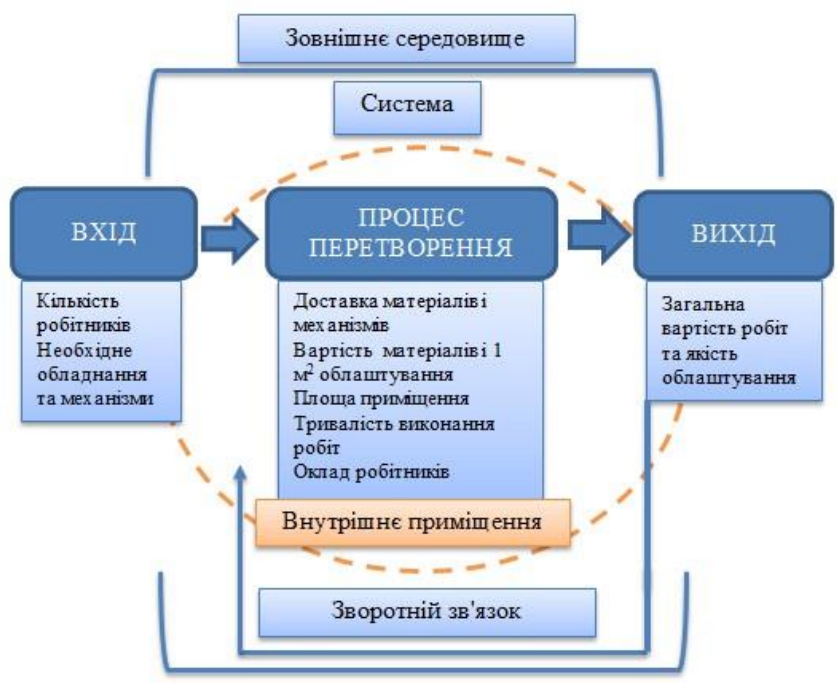

Рис. 1. Системний підхід в організації облаштування внутрішніх приміщень в промисловому та цивільному будівництві

Було обрано конструктивний варіант системного підходу, який пов'язує всі аспекти системи з рішенням актуальної проблеми, включає аналіз факторів зовнішнього середовища, а саме: кількості залучених робітників і необхідного обладнання та механізмів для виконання робіт. У якості базового використаний наступний методологічний алгоритм системного підходу (рис. 2).

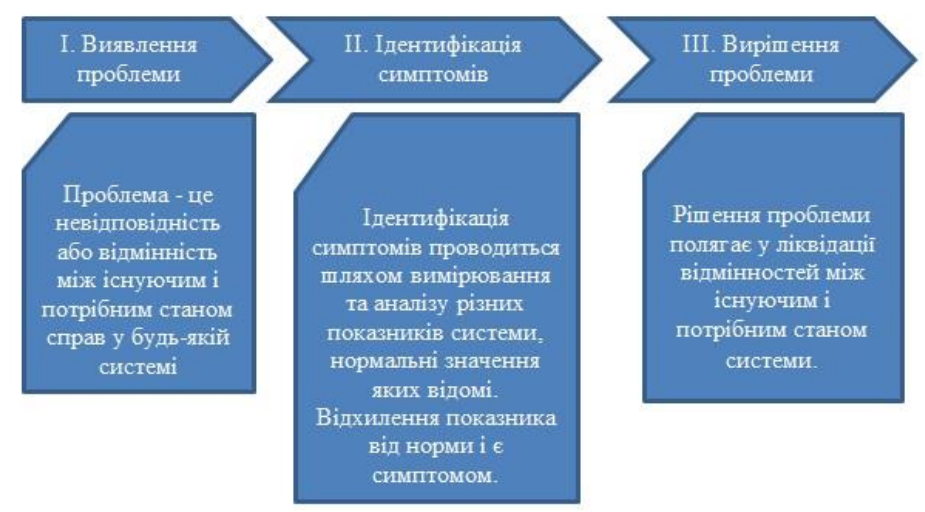

Рис. 2. Алгоритм системного підходу
Механізм дії обраного алгоритму системи наведено на рис. 3.

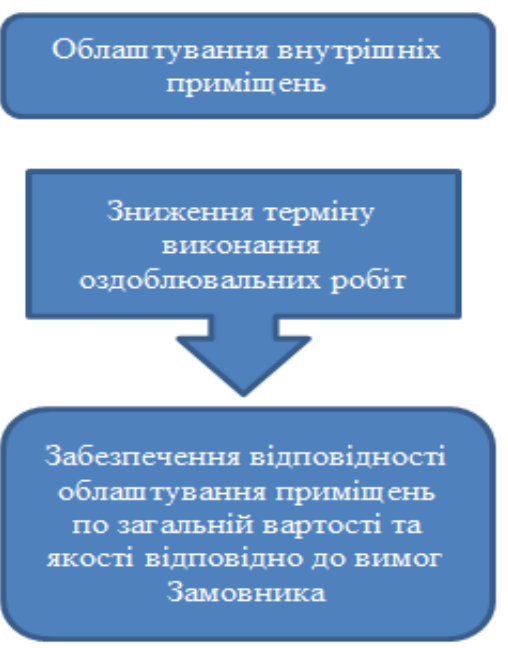

Рис. 3. Механізм дії системи

\section{1. Реалізація механізму дії системи}

На сьогодні багато експертів зазначають, що однією з ключових тенденцій найближчих десятиліть в будівельній індустрії, має стати прискорений перехід від традиційних технологій облаштування до інноваційних, направлених на реалізацію дії запропонованої системи (рис. 3), за рахунок використання моделі графу [9], яка охоплює всі можливі шляхи виконання робіт в дереві та описується залежністю:

$$
V_{\min }=\sum_{i=1}^{\infty} V_{\min }\left(R_{i}\right),
$$

де $V_{\min }\left(R_{i}\right)$ - мінімальна вартість облаштування.

Дана модель направлена на мінімізацію загальної вартості виконання оздоблювальних робіт з облаштування внутрішніх перегородок приміщення загальною площею $63 \mathrm{~m}^{2}$ із залученням традиційних (керамічна цегла) i інноваційних матеріалів (полегшених газоблоків i позогребневих гіпсових плит [10]) із визначенням їх якості:

$$
V\left(R_{i}\right)=S_{i} P_{i}+n_{i} t_{i} c_{i}+G_{i},
$$

де $S_{i}$ - площа облаштування, м²; $P_{i}-$ вартість $1 \mathrm{~m}^{2}$; $n_{i}$ - кількість робітників; $t_{i}-$ тривалість виконання роботи, дні; $c_{i}-$ оклад працівника, грн./год; $G_{i}-$ вартість транспортування матеріалів.

Для реалізації запропонованого механізму дії системи, на основі розрахунків за алгоритмом “жадібності” подальші дослідження були реалізовані за допомогою трьохфакторного симплекс-центрального методу планування експерименту в математичному середовищі Statistica 8.0.

У якості факторів варіювання було обрано: вартість вихідних матеріалів (фактор $\mathrm{X} 1)$, кількість залучених робітників для виконання роботи (фактор Х2) і тривалість виконання робіт (фактор Х3), зміна яких представлена в табл. 1. 
Таблиця 1

Фактори варіювання

\begin{tabular}{|l|c|c|c|c|}
\hline \multicolumn{2}{|c|}{ Фактори, вигляд } & \multicolumn{2}{c|}{ Рівні варіювання } & $\begin{array}{c}\text { Інтервал } \\
\text { варіювання }\end{array}$ \\
\cline { 1 - 4 } натуральний & кодований & нижній 0 & верхній 1 & 152 \\
\hline Вартість матеріалів, грн. & $X 1$ & 372 & 524 & 4 \\
\hline Кількість робітників, чол. & $X 2$ & 2 & 6 & 4 \\
\hline Тривалість виконання робіт, дні & $X 3$ & 3 & 9 & 4 \\
\hline
\end{tabular}

У якості вихідних параметрів було обрано загальну вартість $(V 2 \rightarrow \min )$ і якість виконання робіт $(V 2 \rightarrow$ max $)$. Оцінку якості облаштування перегородок 3 традиційних і інноваційних матеріалів проводили по 5-ти бальній шкалі: 5 - висока; 3 - середня; 1 - низька.

Матриця експерименту та іï математична реалізація приведена в табл. 2. У результаті моделювання отримані рівняння регресії (3)-(4) і побудовані тернарні поверхні змін вихідних параметрів в залежності від змін варійованих факторів (рис. 4).

Рівняння регресії:

- загальна вартість (грн.)

$V 1=55796.9 X 1+28545.9 X 2+50145.19 X 3-44198.57 X 1 X 2$ $-52902.21 X 1 X 3+27202.29 X 2 X 3-170284.5 X 1 X 2 X 3$;

- якість виконання робіт

$V 2=0.9 X 1+3.19 X 2+2.9 X 3+13.29 X 1 X 2+$ $+0.43 X 1 X 3+4.29 X 2 X 3+18 X 1 X 2 X 3$.
Аналіз отриманих рівнянь регресії (3)-(4) показав, що фактори $X 1, X 2$ і $X 3$ значимі та взаємозв'язані. Зниженню загальної вартості (від 55000 до 30000 грн.) та високої якості (від 2 до 5 балів) робіт по облаштуванню внутрішніх перегородок приміщення (рис. $4, a, 6$ ) сприяє одночасна зміна факторів варіювання: збільшення значень вартості використаних матеріалів від 372 до 524 грн. (фактор $X 1$ ), кількості залучених робітників від 2 до 6 (фактору $X 2$ ) i тривалості виконання робіт від 5 до 7 днів (фактор X3). Після суміщення отриманих тернарних поверхонь одна 3 одною, досить чітко визначається оптимальна область по вихідним критеріям: V2 $\rightarrow$ min i $\mathrm{V} 2 \rightarrow \max$, яка обмежена наченнями варійованих факторів по $X 1$ від 392 до 500 грн., по $X 2$ від 3 до 5 чоловік, по $X 3$ від 5 до 7 днів. Дана область забезпечує мінімальну вартість виконання робіт (менше 35000 грн.) по облаштуванню внутрішніх перегородок за термін у 6 днів.

Таблиця 2

Матриця експерименту та ії математична реалізація

\begin{tabular}{|c|c|c|c|c|c|c|c|c|}
\hline \multirow{2}{*}{$\begin{array}{c}\text { Точки } \\
\text { плану }\end{array}$} & \multicolumn{2}{|c|}{$\begin{array}{c}\text { Матриця плану в } \\
\text { кодованих величинах }\end{array}$} & \multicolumn{2}{|c|}{ Матриця плану в натуральних величинах } & \multicolumn{2}{|c|}{ Вихідні параметри } \\
\cline { 2 - 9 } & $X 1$ & $X 2$ & $X 3$ & $\begin{array}{c}\text { Вартість } \\
\text { матеріалів, грн }\end{array}$ & $\begin{array}{c}\text { Кількість } \\
\text { робітників, чол. }\end{array}$ & $\begin{array}{c}\text { Тривалість } \\
\text { виконання } \\
\text { робіт, дні }\end{array}$ & $\begin{array}{c}\text { Загальна } \\
\text { вартість, грн. }\end{array}$ & Якість \\
\hline 1 & 0,33 & 0,33 & 0,33 & 422,67 & 3,33 & 6,33 & 30756 & 5 \\
\hline 2 & 0,00 & 0,00 & 1,00 & 372 & 2 & 9 & 50735 & 3 \\
\hline 3 & 0,67 & 0,00 & 0,33 & 473,33 & 2 & 6,33 & 43681 & 1 \\
\hline 4 & 0,00 & 0,67 & 0,33 & 372 & 4,67 & 6,33 & 42136 & 3 \\
\hline 5 & 0,00 & 0,33 & 0,67 & 372 & 3,33 & 7,67 & 48645 & 3 \\
\hline 6 & 0,33 & 0,00 & 0,67 & 422,67 & 2 & 7,67 & 38849 & 3 \\
\hline 7 & 0,67 & 0,33 & 0,00 & 473,33 & 3,33 & 5 & 35395 & 5 \\
\hline 8 & 0,33 & 0,67 & 0,00 & 472,67 & 4,67 & 5 & 29304 & 3 \\
\hline 9 & 0,00 & 1,00 & 0,00 & 372 & 6 & 5 & 27932 & 1 \\
\hline 10 & 1,00 & 0,00 & 0,00 & 524 & 2 & 5 & 55821 & 3 \\
\hline
\end{tabular}

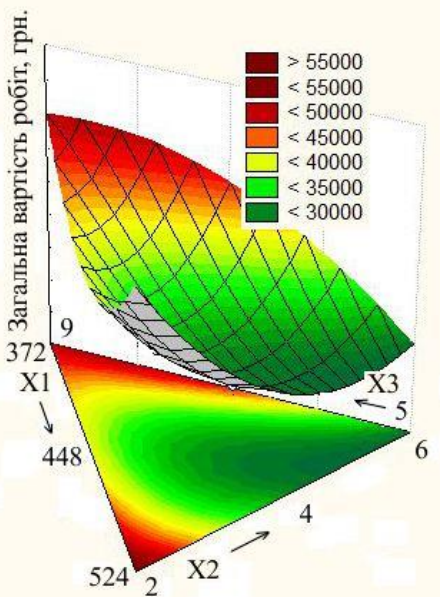

$a$

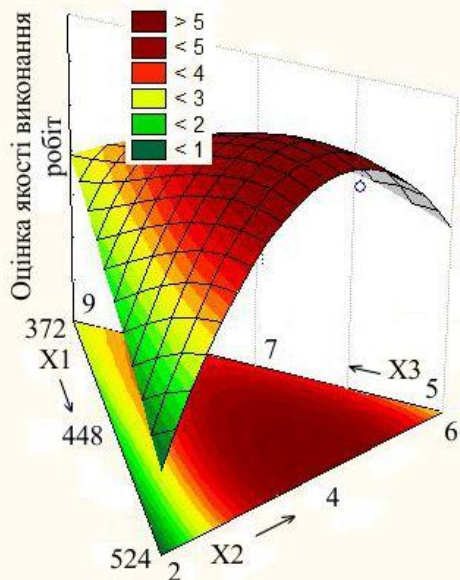

б

Рис. 4. Тернарні поверхні: $a$ - зміни показників загальної вартості виконання; $\sigma$ - якості робіт по облаштуванню внутрішніх перегородок примішення 


\section{4. Висновки}

В результаті проведених досліджень:

1) розроблено алгоритм системного підходу в організації облаштування внутрішніх приміщень в промисловому та цивільному будівництві та запропоновано механізм дії системи;

2) на основі розрахунків за алгоритмом “жадібності” проведено мінімізацію загальної вартості виконання робіт;

3) із залученням трьохфакторного симплексцентрального методу планування експерименту визначено оптимальну область по вихідним критеріям: $\mathrm{V} 2 \rightarrow \min$ i V2 $\rightarrow$ min, яка обмежена значеннями варійованих факторів по $X 1$ від 392 до 500 грн., по $X 2$ від 3 до 5 чоловік, по $X 3$ від 5 до 7 днів. Дана область забезпечує мінімальну вартість виконання робіт (менше 35000 грн.) по облаштуванню внутрішніх перегородок за термін у 6 днів.

Подальші дослідження будуть спрямовані на визначення аналітичних розрахунків процесу облаштування внутрішніх приміщень житлових i промислових будівель, направлених на ліквідацію відмінностей між існуючим і потрібним станом запропонованої системи.

\section{Література}

1. Шепталин, Г. А. Общая теория систем и системный анализ: Учебн. пособие [Текст] / Г. А. Шепталин, Л. И. Шепталина // Челябинск, Изд-во ЮУрГУ, 2007. $-101 \mathrm{c}$.

2. Сурмин, Ю. П. Теория систем и системный анализ: учебное пособие [Текст] / Ю. П. Сурмин. - К.: МАУП, 2003. -368 с.

3. Куликов, Л. М. Основы экономической теории [Текст]: уч. пос. / Л. М. Куликов. - М.: Финансы и статистика, 2002. - 352 с.

4. Chong, H.-Y. Improving Construction Procurement Systems Using Organization Strategies [Text] / H.-Y. Chong, Ch. N. Preece // Acta Polytechnica Hungarica. - 2014. Vol. 11, Issue 1. - P. 5-20. doi: 10.12700/aph.11.01.2014.01.1

5. Yu, W. Development and Application of a Systematic Innovation Procedure for Construction Technology [Text] /W. Yu, Ch.-M. Wu, T. Huang // Proc. $26^{\text {th }}$ Intern. Symp. On Automation and Robotics in Construction (ISARC 2009), Management and Social Issues, 2009. - P. 149-159.

6. Lawson, B. Developing Innovation Capability in Organization: a dynamic capabilities approach [Text] / B. Lawson, D. Samson // International Journal of Innovation
Management. - 2001. - Vol. 5, Issue 3. - P. 377-400. doi: 10.1142/s1363919601000427

7. Теория и практика малоэтажного жилищного строительства в России [Текст] / под ред. А. Н. Асаула. СПб.: Изд-во "Гуманистика", 2005. - 563 с.

8. Чемодуров, В. Т. Методы системного анализа в проектировании технических систем [Текст] / В. Т. Чемодуров, Ю. С. Кузьмина // Строительство и техногенная безопасность. - 2013. - Вып. 46. - С. 30-38.

9. Асапов, М. О. Дискретная математика: графы, матроиды, алгоритмы [Текст]: уч. пос.; 2-е изд, испр. и доп. / М. О. Асапов, В. А. Баранский, В. В. Расин. - СПб: Изд-во Лань, 2010. - 368 с.

10. Довідник по ринку матеріалів для внутрішнього облатування та оздоблення приміщень (за даними 2013 р.) [Текст] / за заг. ред. П. В. Захарченка. - К.: СПД Павленко, 2014. $-264 \mathrm{c}$.

\section{References}

1. Sheptalin, G. A. (2007). Obschaya teoriya system i sistemnuy analiz. Chelyabinsk: Izdatelstvo YuUrGU, 101.

2. Surmin, Yu. P. (2003). Teoriya system i sistemnuy analiz. Kiev: MAUP, 368.

3. Kylikov, L. M. (2002). Osnovu ekonomicheskoy teorii. Moskow: Finansu i statistika, 352.

4. Chong, H.-Y., Preece, Ch. N. (2014). Improving Construction Procurement Systems Using Organization Strategies. Acta Polytechnica Hungarica, 11 (1), 5-20. doi: 10.12700/aph.11.01.2014.01.1

5. Yu, W., Wu, C.-M., Huang, T. (2009). Development and Application of a Systematic Innovation Procedure for Construction Technology. Proc. 26 ${ }^{\text {th }}$ Intern. Symp. On Automation and Robotics in Construction (ISARC 2009), Management and Social Issues, 149-159.

6. Lawson, B., Samson, D. (2001). Developing Innovation Capability in Organization: a dynamic capabilities approach. Intern. J. of Innovation Management, 5 (3) 377-400. doi: $10.1142 / \mathrm{s} 1363919601000427$

7. Asaul, A. N. (2005). Teoriya i practika maloetazhnogo zhulicshnogo stoitelstva v Rossii. SanktPeterburg: Izdatelstvo Gumanistika, 563.

8. Chemodurov, V. T., Kuzmina, Yu. S. (2013). Metodu sistemnogo analiza $\mathrm{v}$ proektirovanii tehnicheskih system. Stoitelstvo i tehnogennaya bezopasnost, 46, 30-38.

9. Asapov, M. O., Baranskuy, V. A., Rassin, V. V. (2010). Diskretnaya matematika: grafu, matroidu, algoritmu. Sankt-Peterburg: Izdatelstvo Lan, 368.

10. Zaharchenko, P. V. et al. (2014). Dovidnuk po runky materialiv dlya vnutrishnogo oblashtuvannya ta ozdoblennya prumischen. Kyiv: Vudavnuctvo SPD Pavlenko, 264.

Рекомендовано до публікації д-р техн. наук Тугай О. А. Дата надходження рукопису 23.01.2015

Коваль Володимир Богданович, аспірант, кафедра менеджменту в будівництві, Київський національний університет будівництва і архітектури, пр. Повітрофлотсьий, 31, м. Київ, Україна, 03680 E-mail: v.koval7@gmail.com 